\title{
Logistics System Design based on Service Oriented Architecture using Thomas Erl Model
}

\author{
Daniel Riano Kaparang \\ Magister Information Systems, \\ Faculty of Information \\ Technology, Satya Wacana \\ Christian University; \\ JI. Diponegoro 52-60 Salatiga, \\ Indonesia. 50711
}

\author{
Wiranto H. Utomo \\ Magister Information Systems, \\ Faculty of Information \\ Technology, Satya Wacana \\ Christian University; \\ Jl. Diponegoro 52-60 Salatiga, \\ Indonesia. 50711
}

\author{
Danny Manongga \\ Magister Information Systems, \\ Faculty of Information \\ Technology, Satya Wacana \\ Christian University; \\ Jl. Diponegoro 52-60 Salatiga, \\ Indonesia. 50711
}

\begin{abstract}
Logistics business process requires data services and information to maintain the availability of logistics, to save time, to minimize risks, and to give benefits. This paper discussed the logistics system designs for small to mediumsized business in the small enterprise scale based on service oriented architecture (SOA). The stages discussed in this paper were based on the model introduced by Thomas Erl,which was intended to determine which of the services were contained in the business process of a system, in this case the logistics system. The result was a logistics system design integrated with SOA.
\end{abstract}

\section{Keywords:}

Logistics, Service Oriented Architecture, Task and Entity, Thomas Erl.

\section{INTRODUCTION}

Business and IT executives in many companies focus on Service-Oriented Architecture because they realize there are incompatibilities on their monumental pressures nowadays. The competitive products and market as well as the capability of the existing systems to increase the company's ability and to reduce the total operational costs [1]. SOA in terms of webbased service needs to be integrated in a company with dynamic business process and focus on inventions in its every business process as service.

Logistics system as the environment in maintaining the stability of goods availability to support the organization's operational. Internal and external factors of the company effect on the availability of the goods needed. Logistics system, in general, sees the impact of goods supply and its distributions in all organizational sectors [2]. Control over this issue further addressed with integrating service in all parts of the logistics system based on SOA.

This paper raised the case study of the logistics system in SatyaWacana Christian University, whereas this university has provided the systems information of the logistics which handles the supply of goods from various suppliers and distribute them to all units/faculties in the university. The problem is there is a need of automation system service for demands, deliveries, and availability of goods in the logistics. This is supported with the issue of number of goods which categorized as high or low mobility. SOA-based automation system is expected to support the saving of time and cost as well as occupy all the units/faculties' needs without any indent items.

\section{RELATED WORKS, RESEARCH PURPOSE AND CONTRIBUTION}

\subsection{Related Works}

A research about automatic business process for checking completeness certificate of diploma using service oriented modeling and architecture (SOMA) [3]. It is purpose to design analysis and comparative in effort to information system integration using SOMA. This study has been developing in Satya Wacana Christian University (SWCU), Department of Administration and Registration. Depend on the experiment, the business process for checking completeness certificate of diploma is more useful for all users who includes in this process.

The other research is about supply chain simulation with collaborative design system basen on SOA with case study in logistic industry [1]. This system purposed for increase productivities and innovation in logistic industry. It has been supporting user to make decision and sharing data. Data management and information exchange supported by service interface which available on SOA. The result was show on figure 1 that describe interaction model depend on requestresponse which were use by services on SOA. It is show more interaction between services, process, information etc.

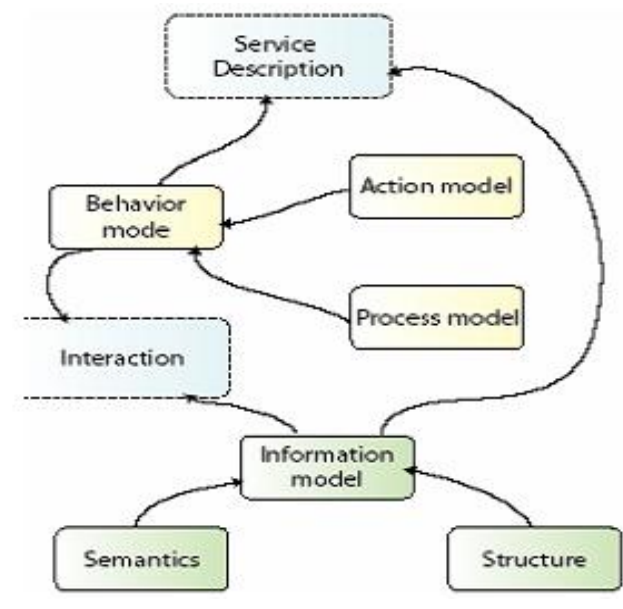

Fig 1: Interaction Model [1] 


\subsection{Research Purpose}

This study is develop design logistic system using SOA purposed for:

1. Identification services which needed for data transaction in working area of Department Logistic based on Erl model.

2. Integrating collaborative data and sharing information for the enterprise systems preparation in SWCU.

3. Comparative system between old logistic system and logistic system using SOA.

\subsection{Research Contribution}

This research contribution are support integration enterprise system based on SOA. So that more accessibility, data management as service oriented in SWCU area. Future more this research can be collaborative system from other departments in SWCU by using SOA. It will be more easier to develop and usable.

\section{LITERATURE REVIEW}

\subsection{Service Oriented Business Process Design}

Service Oriented Architecture (SOA) is model of software engineering which integrated with business process in an information system, formed as a module of standardized components and can be reused by other business processes [4][5][6].

In figure 2, according to Thomas Erl, service is divided into sections, but its scope is varied. Every service handles a process in the business process to the sub-process. It was done to facilitate the addition of new systems without having to alter the existing business process or architecture.

Thomas Erl spells out the steps of constructing a serviceoriented business process design [6]. First step is map out interaction scenarios. This step is designed to find out the needs of service process by sequentially describing the whole business process, whereas the candidate service that will be made based on business process can be obtained from it. The second step, design the process service interface. After finding out the definition of a service process, in the process using tools in web service WSDL will be automatically generalized.

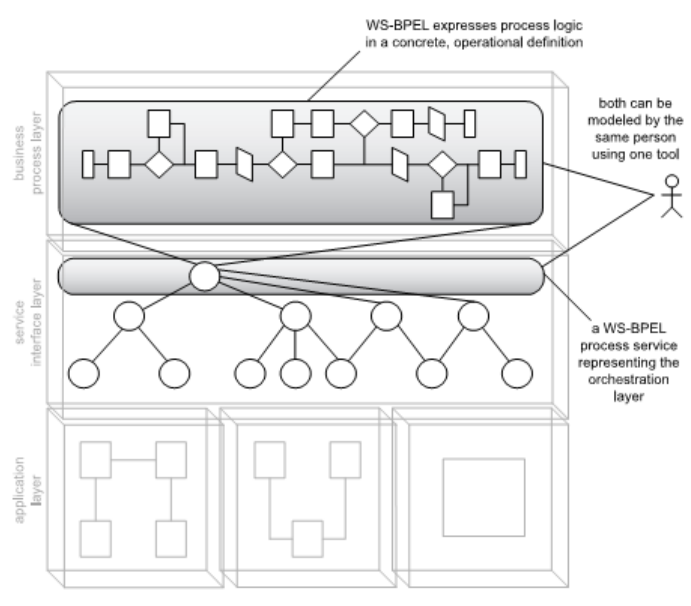

Fig 2: Service Architecture SOA [7]

The third step, formalize partner service conversation. This step will merge the services that had been made previously with interaction with other services. Fourth step, define process logic. This step will evaluate the logics plot of a service that had been made with existing business process. The fifth step, align interaction scenarios and refine process. This step is optional. By doing the scenario interaction from Step 1, whether or not the service made had catered the scenario and being averted from business privacy components issue on distributed application.

\subsection{Logistics System}

Logistic management is a part of supply chain process which comprised by processes of planning, implementing, flow controlling, and storing efficiently, effectively, the availability of goods from production up to consumers to fulfill the customers' needs [8].

Hing Kai Chan et al. suggest a Just-In-Time (JIT) framework for the logistics system [9]. Figure 3 describes the cycle process of a logistics structure with model process components, information system, products, and production design. Those components support each other and integrated according to each functions.

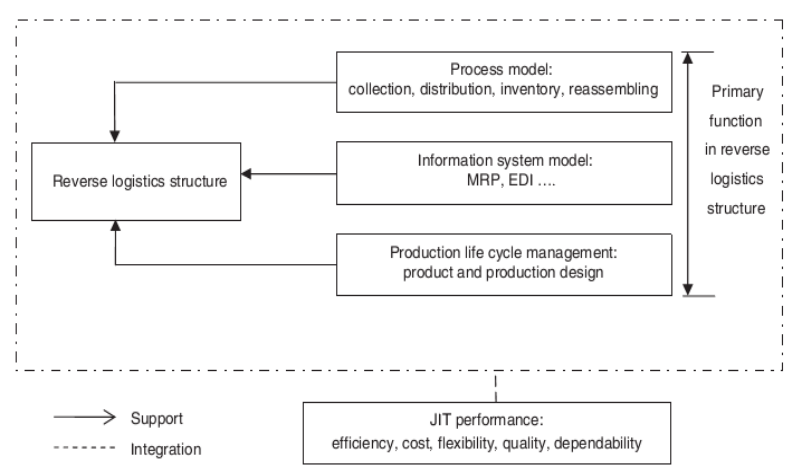

Fig 3: JIT Logistics Framework [9] 


\subsection{Logistics System of Satya Wacana Christian University}

This case study was placed on the Logistics of SatyaWacana Christian University. The business process of this logistics system was divided into two main activities which are ordering goods and distributing goods as shown in Figure 4

The units or faculties filled out a Request Form, the Logistics Department requested the head department's approval of the Request Form, the Logistics Department submitted the Request Form to the Finance Department, the Logistics Department made the summary of item collecting, and units or faculties collected the item requested from the Supply Division. The Finance Department provided the bill to every unit or faculties, the units or faculties discharged the bills from the Finance Division. There were four main actors in this system which are; the Logistics Department as the logistics center, the Finance Department, faculty as the end point distribution, and supplier.

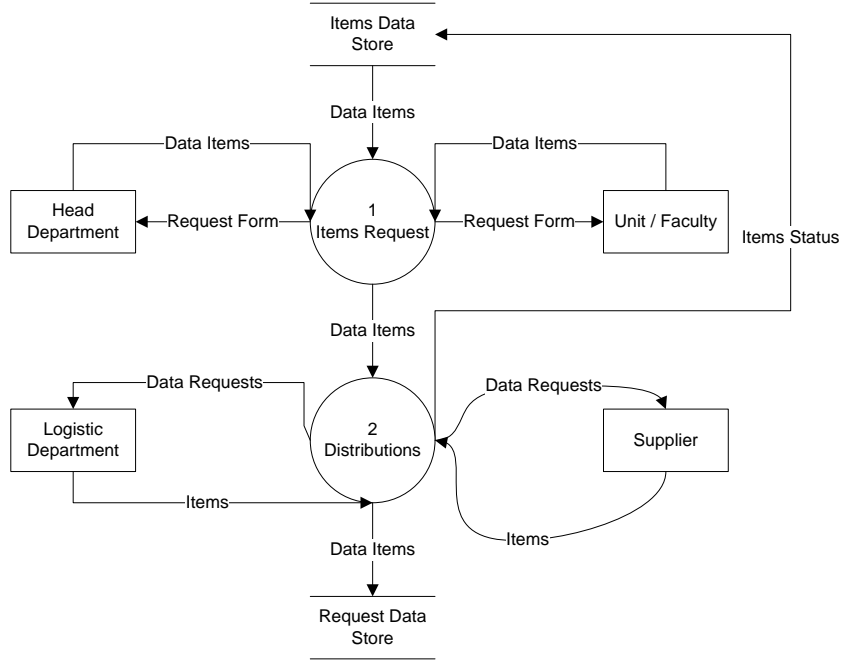

Fig 4: Logistics System of Satya Wacana Christian University

\section{SERVICE CANDIDATES}

The things that need to be considered when specifying a service candidates is to know ascertain the existing business process, the involved actors, what kind of service is needed, and the data flow (Figure 4). The candidates found are being recorded in detail along with their functionalities. Thereafter, the service candidates were divided into; entity service and task service. The service candidates found were listed in Table 1 which separated them into task and entity.

Business process mapping to service candidates were conducted. Service candidates were divided into entity service and task service. While the business process was divided into four main business process, which are; ordering by the unit or faculty to Logistics Department, ordering by Logistics Department to supplier, distribution from supplier to Logistics Department, and distribution from Logistics Department to unit or faculty. 
Table 1: List of Services

\begin{tabular}{|c|c|c|c|c|}
\hline No. & $\begin{array}{l}\text { Business } \\
\text { Process }\end{array}$ & Service Candidates & Elected Entity Services & Elected Task Services \\
\hline 1. & $\begin{array}{l}\text { Ordering by the } \\
\text { unit or faculty to } \\
\text { Logistics } \\
\text { Department }\end{array}$ & $\begin{array}{l}\text { a. } \quad \text { List } \\
\quad \text { Services } \\
\text { - Service } \\
\text { GetDataBarang } \\
\text { - Service } \\
\text { SetDataPemesanan } \\
\text { - Service } \\
\text { GetDataAnggaran } \\
\text { - Service } \\
\text { PrintDataPesanan } \\
\text { - Service } \\
\text { RekapDataPesanan } \\
\text { - Service } \\
\text { BooleanCheckValue } \\
\\
\\
\text { b. List } \\
\quad \text { Services } \\
\text { - Service GetIDBarang } \\
\text { - Service } \\
\text { GetNamaBarang } \\
\text { - Service } \\
\text { GetHargaSatuan } \\
\text { - Service } \\
\text { GetIDPesanan } \\
\text { - Service } \\
\text { GetUnitPemesan } \\
\text { - Service } \\
\text { GetNoRekening } \\
\text { - Service } \\
\text { GetNamaBank } \\
\text { - Service SetIDBarang } \\
\text { - Service } \\
\text { SetNamaBarang } \\
\text { - Service } \\
\text { SetHargaSatuan } \\
\text { - Service } \\
\text { SetIDPesanan } \\
\text { - Service } \\
\text { SetUnitPemesan } \\
\text { - Service } \\
\text { - SetNoRekening } \\
\text { - Service } \\
\text { SetNamaBank }\end{array}$ & $\begin{array}{l}\text { - Service GetIDBarang } \\
\text { (used by the unit or faculty to view } \\
\text { items to be ordered stock list) } \\
\text { - Service SetIDBarang } \\
\text { (used by the unit or faculty to order } \\
\text { the items which in the form of item } \\
\text { data input) } \\
\text { - ServiceSetIDPesanan } \\
\text { (used as the key to identify the } \\
\text { requester which henceforth can be } \\
\text { checked by the system or admin } \\
\text { - Service SetNoRekening } \\
\text { (used to input the unit or faculty's } \\
\text { account data) }\end{array}$ & $\begin{array}{l}\text { - Service GetDataBarang } \\
\text { (Handles the process of partially or } \\
\text { whole fully information collecting of } \\
\text { the requsted items data.) } \\
\text { - Service SetDataBarang } \\
\text { (handles the data input of requested } \\
\text { items of the units or faculty, including } \\
\text { budget data) } \\
\text { - Service BooleanCheckValue } \\
\text { (handles the exception process of the } \\
\text { orders) }\end{array}$ \\
\hline 2. & $\begin{array}{ll}\text { Ordering } & \text { by } \\
\text { Logistics } & \\
\text { Department } & \text { to } \\
\text { supplier } & \end{array}$ & $\begin{array}{l}\text { a. List Task Services } \\
\text { - Service } \\
\text { GetDataSupplier } \\
\text { - Service } \\
\text { GetDataBarang } \\
\text { - Service } \\
\text { GetDataPurchase } \\
\text { - Service } \\
\text { UpdateStatDelivery } \\
\text { - Service } \\
\text { BooleanCheckValue } \\
\text { - Service } \\
\text { PesananToSupplier } \\
\text { b. List Bntity } \\
\text { Services }\end{array}$ & $\begin{array}{l}\text { - Service SetIDUser } \\
\text { (used by the Logistics Department } \\
\text { personnel to the supplier as the } \\
\text { identification) } \\
\text { - Service GetIDUser } \\
\text { (used by the supplier to identify the } \\
\text { personnel that order the item) } \\
\text { - Service GetIDBarang } \\
\text { (used by the Logistics Department } \\
\text { personnel to acquire } \\
\text { informationsregarding items to be } \\
\text { ordered) - Service SetIDBarang } \\
\text { (used by the Logistics Department } \\
\text { personnel to input order data for the }\end{array}$ & $\begin{array}{l}\text { - Service GetDataSupplier } \\
\text { (handles the process of partially or } \\
\text { wholefully information collecting of } \\
\text { the requsted items data for the } \\
\text { supplier) } \\
\text { - Service GetDataBarang } \\
\text { (used to provide informations of sold } \\
\text { out or about to sold out items to be } \\
\text { ordered to the supplier) } \\
\text { - Service PesananToSupplier } \\
\text { (used to send the order data which } \\
\text { contains the user ID, ordered items } \\
\text { data, and supplier data) } \\
\text { - ServiceBooleanCheckValue }\end{array}$ \\
\hline
\end{tabular}




\begin{tabular}{|c|c|c|c|c|}
\hline No. & $\begin{array}{l}\text { Business } \\
\text { Process }\end{array}$ & Service Candidates & Elected Entity Services & Elected Task Services \\
\hline & & $\begin{array}{l}\text { - Service GetIDBarang } \\
\text { - Service } \\
\text { GetNamaBarang } \\
\text { - Service } \\
\text { GetHargaSatuan } \\
\text { - Service SetIDBarang } \\
\text { - Service } \\
\text { SetNamaBarang } \\
\text { - Service } \\
\text { SetHargaSatuan } \\
\text { - Service } \\
\text { GetIDSupplier } \\
\text { - Service } \\
\text { GetNamaSupplier } \\
\text { - Service } \\
\text { GetAlamatSupplier } \\
\text { - Service } \\
\text { GetTlpSupplier } \\
\text { - Service } \\
\text { SetIDSupplier } \\
\text { - Service } \\
\text { SetNamaSupplier } \\
\text { - Service } \\
\text { SetAlamatSupplier } \\
\text { - Service } \\
\text { SetTlpSupplier } \\
\text { - Service GetIDUser } \\
\text { - Service } \\
\text { GetNamaUser } \\
\text { - Service GetDate } \\
\text { - Service SetIDUser } \\
\text { - Service SetNamaUser } \\
\text { - Service SetDate }\end{array}$ & supplier) & $\begin{array}{l}\text { (handles the exception process of the } \\
\text { orders) }\end{array}$ \\
\hline 3. & $\begin{array}{l}\text { Distribution } \\
\text { from supplier to } \\
\text { Logistics } \\
\text { Department }\end{array}$ & $\begin{array}{l}\text { a. } \quad \text { List } \\
\quad \text { Services } \\
\text { - Service } \\
\text { GetDataSupplier } \\
\text { - Service } \\
\text { SetDataBarang } \\
\text { - Service } \\
\text { SetDataPurchase } \\
\text { - Service } \\
\text { UpdateStatDelivery } \\
\text { - Service } \\
\text { UpdateDataBarang } \\
\text { - Service } \\
\text { BooleanCheckValue } \\
\\
\\
\text { b. List } \\
\quad \text { Services } \\
\text { - Service } \\
\text { GetIDSupplier } \\
\text { - Service } \\
\text { GetNamaSupplier } \\
\text { - Service } \\
\text { GetAlamatSupplier } \\
\text { - Service } \\
\text { GetTlpSupplier } \\
\text { - Service } \\
\text { SetIDSupplier } \\
\text { - Service }\end{array}$ & $\begin{array}{l}\text { - Service SetIDSupplier } \\
\text { (Usedsent information from the } \\
\text { supplier to the Logistics Department } \\
\text { in the items distribution process.) } \\
\text { - Service GetIDSupplier } \\
\text { (used to inform the Logistics } \\
\text { Department concerning the items } \\
\text { distribution by the supplier) } \\
\text { - Service SetIDBarang } \\
\text { (used to update items data when } \\
\text { being delivered and to track the items } \\
\text { distribution) }\end{array}$ & $\begin{array}{l}\text { - Service SetDataSupplier } \\
\text { (Used by the supplier to fill out forms } \\
\text { of items delivery when its ready to be } \\
\text { delivered.) } \\
\text { - Service UpdateStatDelivery } \\
\text { (Provides information of items } \\
\text { delivery from the supplier and the } \\
\text { items tracking process. Includes the } \\
\text { bill and its description of the } \\
\text { condition) } \\
\text { - ServiceBooleanCheckValue } \\
\text { (handles the exception process of the } \\
\text { orders) }\end{array}$ \\
\hline
\end{tabular}




\begin{tabular}{|c|c|c|c|c|}
\hline No. & $\begin{array}{l}\text { Business } \\
\text { Process }\end{array}$ & Service Candidates & Elected Entity Services & Elected Task Services \\
\hline & & $\begin{array}{ll} & \text { SetNamaSupplier } \\
\text { - Service } & \text { SetAlamatSupplier } \\
\text { - Service GetIDBarang } \\
\text { - Service } \\
\text { GetNamaBarang } \\
\text { - Service } \\
\text { GetHargaSatuan } \\
\text { - Service SetIDBarang } \\
\text { - Service } \\
\text { SetNamaBarang } \\
\text { - Service } \\
\text { SetHargaSatuan }\end{array}$ & & \\
\hline 4. & $\begin{array}{l}\text { Distribution } \\
\text { from } \\
\text { Logististics } \\
\text { Department to } \\
\text { unit or faculty }\end{array}$ & $\begin{array}{l}\text { a. List } \quad \text { Task } \\
\text { Services } \\
\text { - Service } \\
\text { UpdateDataBarang } \\
\text { - Service } \\
\text { UpdateDataPengguna } \\
\text { an } \\
\text { - Service } \\
\text { UpdateDataAnggaran } \\
\text { - Service } \\
\text { BooleanCheckValue } \\
\text { b. List } \\
\quad \text { Services } \\
\text { - Service GetIDBarang } \\
\text { - Service } \\
\text { GetNamaBarang } \\
\text { - Service } \\
\text { GetHargaSatuan } \\
\text { - Service SetIDBarang } \\
\text { - Service } \\
\text { SetNamaBarang } \\
\text { - Service } \\
\text { SetHargaSatuan } \\
\text { - Service } \\
\text { GetIDPesanan } \\
\text { - Service } \\
\text { GetUnitPemesan } \\
\text { - Service } \\
\text { GetNoRekening } \\
\text { - Service } \\
\text { GetNamaBank }\end{array}$ & $\begin{array}{l}\text { - Service GetIDPesanan } \\
\text { (provides the unist or faculty's } \\
\text { ordering data to be forwarded to the } \\
\text { unit or faculty) } \\
\text { - Service SetNoRekening } \\
\text { (to view the budget data that needs to } \\
\text { be repaid by unit or faculty) } \\
\text { - Service GetIDBarang } \\
\text { (to view the data of the items used by } \\
\text { the unit or faculty) }\end{array}$ & $\begin{array}{l}\text { - Service UpdateDataBarang } \\
\text { (used to update the data of the items } \\
\text { issued from the Logistics Department } \\
\text { to unit or faculty) } \\
\text { - Service UpdateDataPenggunaan } \\
\text { (used by unit or faculty to update the } \\
\text { items used as an information for the } \\
\text { Logistics Department) } \\
\text { - Service UpdateDataAnggaran } \\
\text { (used by unit or faculty to bridge the } \\
\text { items acquittal. Also used by the } \\
\text { Logistics Department to keep updates } \\
\text { of the unit or faculty's budget data) } \\
\text { - ServiceBooleanCheckValue } \\
\text { (handles the exception process of the } \\
\text { distribution) }\end{array}$ \\
\hline
\end{tabular}


First mapping was conducted towards the business process ordering by the unit or faculty to Logistics Department. This mapping pinned in Figure 5. Entity service was made in sequential data that initiate every field data as an object. Sequential Data 1 contained service of unit's budget data entity and Sequential Data 2 contained service of items data entity.

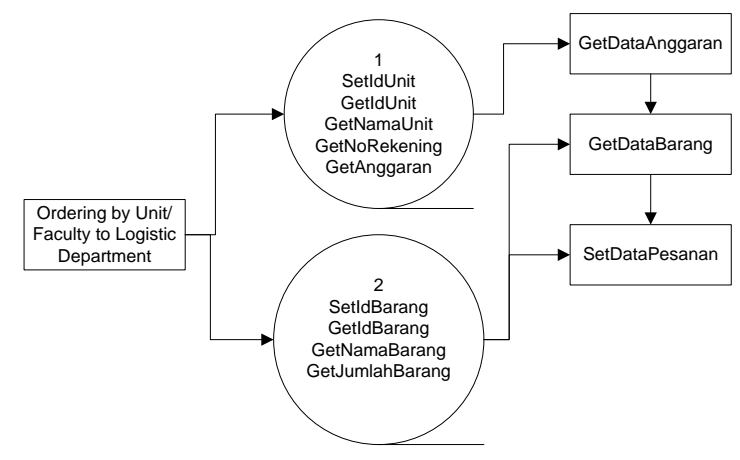

Fig 5: Service of Business Process Ordering by The Unit or Faculty to Logistics Department.

In determining task service on business process ordering by Logistics Department to supplier, a number of services from the entity service that support a task service are needed. For example when unit or faculty wanted to order item, they needed SetIdUnit service to obtain the budget data according to unit or faculty's ID. SetIdBarang was also needed to obtain data of the items to be ordered. This is to view the availability of the items in Logistics Department; hence unit or faculty can determine the number of items to order.

The second mapping was conducted on the business process ordering by Logistics Department to supplier. This mapping was described in Figure 6. Entity service consisted of; 1) items entity, and 2) supplierentity. There were four task services that were sustainably building the data relation of sequential data entity service.

Service GetDataBarang collected the necessary data out of sequential data items entity. Service GetDataSuppliercollected the necessary data out of sequential data supplier entity. Service GetDataPurchasecollected the necessary data out of service GetHargaBarang on items entity and GetHargaBarang on supplier entity. Service UpdateDeliveryStatus was run when the items ordered to supplier had been confirmed on deliverance. This service consisted of three statuses, which are; OK, DELIVERED, and RECEIVED. Status OK meant that the items are ready to be delivered, DELIVERED meant it is on delivery, and RECEIVED meant the items had been received.

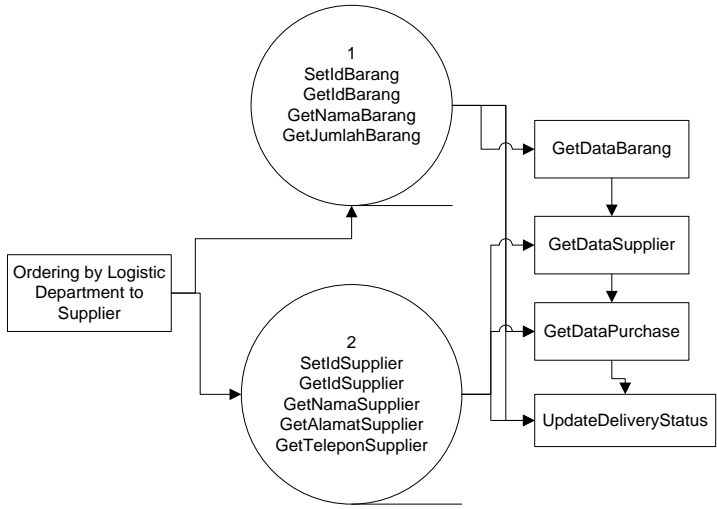

Fig 6: Service of Business Process Ordering by Logistics Department to Supplier.

Third mapping was conducted on business process distribution from supplier to Logistics Department as shown in Figure 7. Entity services consisted of; 1) items entity, and 2) supplier entity. In task services there were SetDataBarang to input data of items that had been delivered to Logistics Department using service GetDataSupplier that had been integrated with service SetDataPurchase, hence automatically service UpdateDataBarang obtained. After the items data updated, the delivery status would automatically updated to RECEIVED.

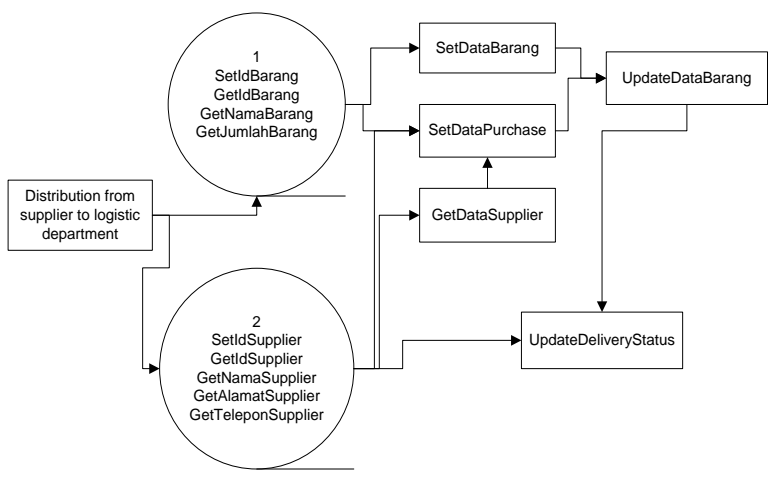

Fig 7: Service ofbusiness process distribution from supplier to Logistics Department.

Fourth mapping was conducted on business process distribution from Logistics Department to unit or faculty as shown in Figure 8. Entity services consisted of; 1) unit entity, and 2) items entity. There were three task services, which are; UpdateDataAnggaran which received update data of items delivery transaction from Logistics Department to unit or faculty. This service can reduce budget available of unit or faculty who conducts the transaction. After the budget updated, service UpdateDataBarang would automatically ran to update the items stocked data in the unit or faculty. All items used were provided by service UpdateDataPenggunaan in means of usage control and items stockings. This is also useful as a warning in case the items stock ran out or diminishes. 


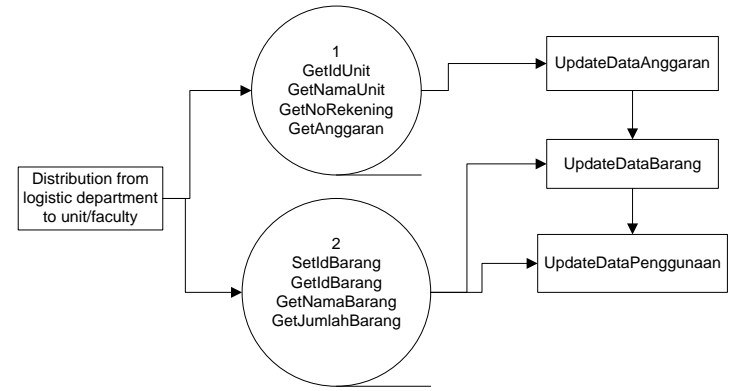

Fig 8: Service of Business Process Distribution from Logistics Department to Unit or Faculty.

\section{SERVICE INTERFACE DESIGN AND WEB SERVICE ANALYSIS}

\subsection{Service Interface}

This stage would describe the design of service candidates that had been mapped before according to its business process in the form of interface. In this case, interface would be a system builder components in the logistics system scope. This discussion was conducted on business process ordering by the unit or faculty to Logistics Department and ordering by the Logistics Department to supplier.For example, in the case study, we provided services interface which is GetDataBarang as the service to collect all the items data which is being used when unit or faculty needed information of items availability and service GetIDBarang was used as single item data collector by item's ID. These service was used in the items ordering by unit or faculty to Logistics Department and by the Logistics Deparment to supplier. By using Netbeans 7.1 tools, the intended service described in Figure 9.

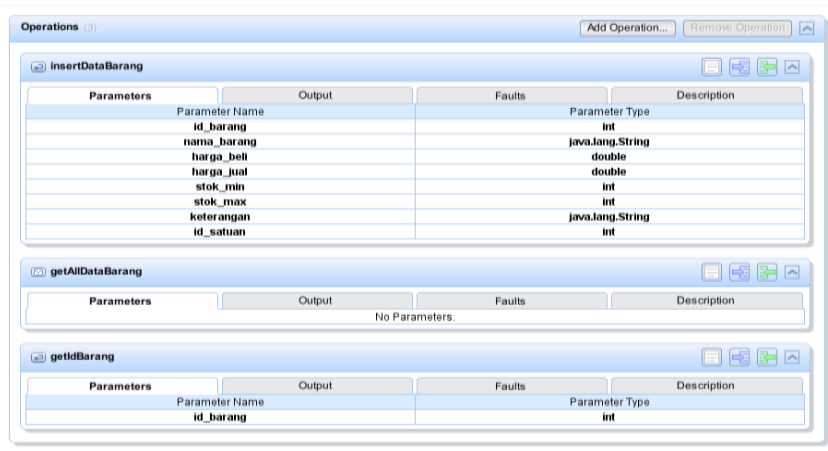

Fig 9: Items Transaction Data Service Interface.

In this stage, all the services built based on existing logistics business process were combined. The WSDL created was communicating through services, henceforth service that needed for a particular business process can be reused. This process was described in Figure 3.There were a communication between web service components in this stage; they were UDDI, WSDL, SOAP, and internet protocol. UDDI act as information provider of available services list as well as their technical details of accessibility.
WSDL explained web service functions to inform request and response format of a service. SOAP was a protocol language that was used on a transaction process through HTTP. SOAL implemented WSDL in request and response. The following was an example of request and response SOAP conducted along with its WSDL code to call service GetIDBarang. Figure 10 was a result of WSDL file generated into XML file format and there were the definitions of server name, port, and host.

\subsection{Trial and Analysis Towards Service Integration Through Web Service}

Trial was conducted by calling the particular service. The trial's results could be seen on method invocation trace file as a result of generate testing web service. Herewith, file WSDL with obvious structure function service could be seen. In the service trial, there were; (1) parameter with element name GetIDBarang, data type integer value return, (2) SOAP request that contained passing by value of the created parameter, (3) binding service and data in SOAP scheme, and (4) SOAP response that contained the result of service request that assigned true if fulfilled/true and false if not fulfilled/false.The next stage of Thomas Erl's was defining process logic. This stage discussed the logics of business process distribution from Logistics Department to unit or faculty. Three task services in this business process could not run without clear logics. Data that are needed to UpdateDataAnggaran consisted of ID unit data and unit name which obtained from entity service GetIDUnit and GetNamaUnit, thereafter remaining budget data which obtained from entity service GetSisaAnggaran. After that, service UpdateDataBarang can be ran. If TRUE, then the items data will be updated automatically.

Throughout the items used by unit or faculty, whole record were conducted, therefore the number of stocks can be handled properly. This matter was handled by service UpdateDataPenggunaan. This service provided control and warning service. If stocks were diminishing or diminished, the system will warn the user to commit ordering. The last stage was align interaction scenarios and refine process. In business process, distribution from supplier to Logistics Department, there were access limit that could be viewed and used by supplier. For example, supplier wanted to see the data of items requested by Logistics Department,and then the items requested data only that the supplier could see. The main actor service in this was entity service such as GetIDBarang,GetNamaBarang,GetJumlahPesanan. This service would send only the requested items data, without being able to manipulated by the supplier. Likewise, for the price offered by supplier through service SetHargaBarangSupplier, can only be seen by Logistics department with the provided service GetHargaBarangSupplier. 


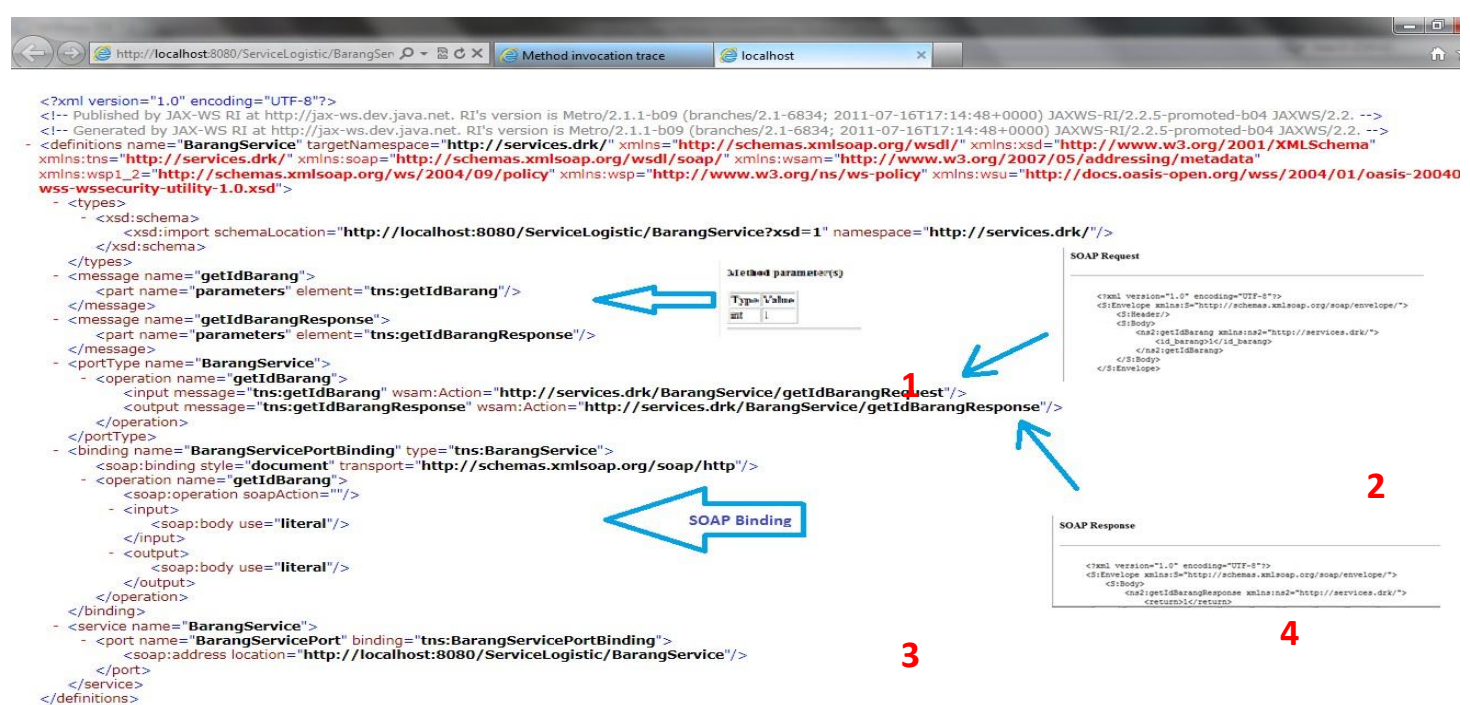

Fig 10: WSDL File of BarangService

Based on the result, this system design was compare with the old logistic system. It is show on Table 2. Logistic system design using SOA is more innovative than the old logistic system. It is possible to make automatic notification, purchase, items order and more.

Table 2: Comparative Old Logistic System with Logistic System Using SOA

\begin{tabular}{|c|c|c|}
\hline $\begin{array}{l}\text { Business } \\
\text { Process }\end{array}$ & Old Logistic System & $\begin{array}{ll}\text { Logistic } & \text { System } \\
\text { Using SOA } & \end{array}$ \\
\hline $\begin{array}{l}\text { Ordering by } \\
\text { the unit or } \\
\text { faculty to } \\
\text { Logistics } \\
\text { Department }\end{array}$ & $\begin{array}{l}\text { - Manual } \\
\text { requirement } \\
\text { items by unit or } \\
\text { faculty. } \\
\text { - Manual } \\
\text { confirmation by } \\
\text { Logistic } \\
\text { Department. }\end{array}$ & 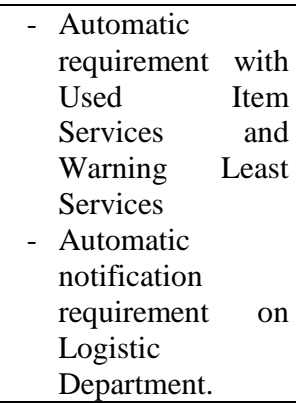 \\
\hline $\begin{array}{l}\text { Ordering by } \\
\text { Logistics } \\
\text { Department } \\
\text { to supplier }\end{array}$ & $\begin{array}{l}\text { - Manual } \\
\text { requirement } \\
\text { items by Logistic } \\
\text { Department using } \\
\text { form item lists } \\
\text { - Manual } \\
\text { notification } \\
\text { available items } \\
\text { from supplier }\end{array}$ & $\begin{array}{l}\text { - Automatic } \\
\text { requirement items } \\
\text { to supplier using } \\
\text { Warning } \\
\text { Warehouse Least } \\
\text { Service } \\
\text { - Automatic } \\
\text { confirmation } \\
\text { available items if } \\
\text { the item is exist. }\end{array}$ \\
\hline $\begin{array}{l}\text { Distribution } \\
\text { from } \\
\text { supplier to } \\
\text { Logistics } \\
\text { Department }\end{array}$ & $\begin{array}{l}\text { - No tracking. } \\
\text { - Online reporting } \\
\text { is not available } \\
\text { - Manual purchase }\end{array}$ & $\begin{array}{l}\text { - Tracking system } \\
\text { using services } \\
\text { - Online reporting } \\
\text { is available } \\
\text { - Possibility for } \\
\text { online purchase }\end{array}$ \\
\hline $\begin{array}{l}\text { Distribution } \\
\text { from } \\
\text { Logististics } \\
\text { Department } \\
\text { to unit or } \\
\text { faculty }\end{array}$ & $\begin{array}{l}\text { - Manual input } \\
\text { items used } \\
\text { - No tracking }\end{array}$ & 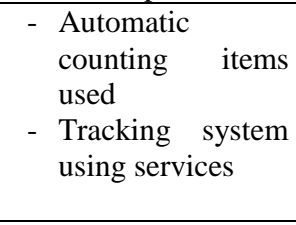 \\
\hline
\end{tabular}

\section{CONCLUSION}

Service Oriented Architecture can be applied in logistics system with consideration towards the service building stages in every existing business process. The stages described by Thomas Erl defined the interaction between services towards business process by users, as well as data security guarantee by dividing service into task service and entity service. Furthermore, this research can integrate design that had been made into real application with trials towards service builder parameters and business process. Grid computing technology is highly recommended for further research in its use of large amount data handling and limitation of data access based on user's access rights.

\section{REFERENCES}

[1] Jin Hai Zeng., Liu WenJu., Ke Yong Zhen. "Supply Chain Simulation: Collaborative Design System Based On SOA - A Case Study in Logistic Industry-" Proceeding of World Academy of Science, Engineering and Technology., Volume 29, May 2008.

[2] Uvarov Sergey. "Problems Of Logistic Systems Sustainable Development In Delivery Chains" Scientific Journal of Logistics, Volume 7, Issue 4, No. 6. ISSN 1734-459X.

[3] Dewi Christine., Danny Manongga., Wiranto H. Utomo. Otomatisasi Proses Bisnis Pengecekan Kelengkapan Pengambilan Ijasah Menggunakan Serive-Oriented Modelling and Architecture (SOMA) (Studi Kasus: Universitas Kristen Satya Wacana). Thesis Magister of Information Systems, Satya Wacana Christian University. 2012.

[4] Hasan Jeffrey. "Expert Service Oriented Architecture in C\# Using the Web Services Enhancements 2.0". Appress, New York. 2006. 
[5] Brown Paul C. "Implementating SOA: Total Architecture in Practice." Addison Wesley Professional, Massachusetts.

[6] Bieberstein., et al. "Executing SOA: A Practical Guide for The Service Oriented Architecture" IBM Press, Indiana.

[7] Erl Thomas. "Service Oriented Architecture: Concepts, Technology and Design.” Prentice Hall PTR, Indiana.
[8] Rahayu Dina RR. "Model Development Supply Chain Performance Measurement System. Case Study: Directorate Aero-structure PT. Dirgantara Indonesia" Thesis Magister Teknik dan Manajemen Industri, Institut Teknologi Bandung. 2009.

[9] Chan Hing Kai., et al. "Implementing Just-In-Time Philosophy to Reverse Logistics Systems: A Review." International Journal of Production Research., Volume 48, No. 21, November 2010 